\title{
Medication administration safety assessment tool: Construction and validation
}

Instrumento para avaliação da segurança na administração de medicamentos: construção e validação Instrumento de evaluación de la seguridad en la administración de medicamentos: Construcción y validación

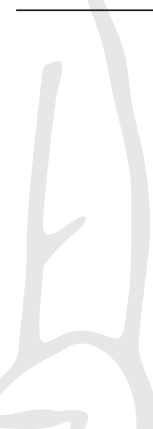
ORCID: 0000-0003-3902-8046

Rhanna Emanuela Fontenele Lima de Carvalho" ORCID: 0000-0002-3406-9685

Paulo César de Almeida" ORCID: 0000-0002-2867-802X

'Universidade Federal do Ceará. Fortaleza-CE, Brasil. "Universidade Estadual do Ceará. Fortaleza-CE, Brasil.

How to cite this article:

Araújo PR, Lima FET, Ferreira MKM, Oliveira SKP, Carvalho REFL, Almeida PC. Medication administration safety assessment tool: construction and validation. Rev Bras Enferm. 2019;72(2):329-36. doi: http://dx.doi.org/10.1590/0034-7167-2018-0340

Corresponding Author: Patrícia Rebouças Araújo E-mail: enfapatriciaaraujo@yahoo.com.br

Submission: 05-17-2018

Approval 08-12-2018

\section{ABSTRACT}

Objective: To build and validate the Patient Safety Assessment in Medication Administration (ASPAM - Avaliação da Segurança do Paciente na Administração de Medicamentos) tool. Method: Methodological study in which the construction, Content Validation Index $(\mathrm{CVI})$, construct validation (factorial analysis) and reliability were performed in terms of homogeneity (Cronbach's Alpha). Results: The ASPAM reached CVI of 0.77 for simplicity, 0.76 for clarity and 0.93 for relevance. The exploratory factorial analysis was adequate for the tool (Kaiser-Meyer-Olkim of 0.66 and Bartlett's sphericity with $p<0.001$ ). The Cronbach's Alpha end of the scale with 28 items was 0.85 . Conclusion: The ASPAM tool was valid and reliable for the identification of risk-generating conditions for the occurrence of Adverse Drug Events.

Descriptors: Patient Safety; Drug Utilization; Validation Studies; Medication Errors; Nursing Care.

\section{RESUMO}

Objetivo: Construir e validar o instrumento Avaliação da Segurança do Paciente na Administração de Medicamentos (ASPAM). Método: Estudo metodológico em que se procederam a construção, o Índice de Validação de Conteúdo (IVC), a validação de construto (análise fatorial) e a confiabilidade, em termos de homogeneidade (Alfa de Cronbach). Resultados: A ASPAM alcançou IVC de 0,77 para simplicidade, 0,76 para clareza e 0,93 para relevância. A análise fatorial exploratória mostrou-se adequada para o instrumento (Kaiser- Meyer-Olkim de 0,66 e a esfericidade de Bartlett com $p<0,001$ ). O Alfa de Cronbach final da escala com 28 itens foi de 0,85. Conclusão: $O$ instrumento ASPAM mostrou-se válido e confiável para a identificação de condições geradoras de risco para ocorrência de eventos adversos aos medicamentos.

Descritores: Segurança do Paciente; Uso de Medicamentos; Estudos de Validação; Erros de Medicação; Cuidados de Enfermagem.

\section{RESUMEN}

Objetivo: Construir y validar el instrumento Evaluación de la Seguridad del Paciente en la Administración de Medicamentos (ASPAM - Avaliação da Segurança do Paciente na Administração de Medicamentos). Método: El estudio metodológico en que se procedió a la construcción, el Índice de Validación de Contenido (IVC), la validación de constructo (análisis factorial) y la confiabilidad, en términos de homogeneidad (Alfa de Cronbach). Resultados: La ASPAM alcanzó IVC de 0,77 para simplicidad, 0,76 para claridad y 0,93 para relevancia. El análisis factorial exploratorio se mostró adecuado para el instrumento (Kaiser-Meyer-Olkim de 0,66 y la esfericidad de Bartlett con $p<0,001$ ). El Alfa de Cronbach final de la escala con 28 ítems fue de 0,85. Conclusión: El instrumento ASPAM se mostró válido y confiable para la identificación de condiciones generadoras de riesgo para ocurrencia de eventos adversos a los medicamentos.

Descriptores: Seguridad del Paciente; Utilización de Medicamentos; Estudios de Validación; Errores de Medicación; Cuidados de Enfermería. 


\section{INTRODUCTION}

Medication error is defined as any avoidable event that may cause or induce the inappropriate use of medication or harm the patient and may be considered an Adverse Drug Event (ADE) when the event generates harm to the patient ${ }^{(1)}$.

A retrospective study, developed in a Brazilian university hospital based on the analysis of 263 medical records, identified that 58 patients had at least one ADE during their hospitalization period, which led to an incidence of $22.1 \%$, with 83 distinct ADEs identified, resulting in a rate of 31.5 ADE per 100 patients $^{(2)}$.

Another retrospective study, conducted in a quaternary hospital in São Paulo countryside, found a record of 16,753 medication errors during the period 2007 to 2013, which corresponds to an incidence of $1.4 \%{ }^{(3)}$.

The Ministry of Health (MoH) and the Brazilian National Health Surveillance Agency (ANVISA - Agência Nacional de Vigilância Sanitária), in order to prevent and reduce the incidence of such adverse events in health services, published in 2013, the Safety, Prescription, Use and Administration of Medication Protocol, to be applied in all establishments providing health care at all levels of complexity where medications are used for prophylaxis, diagnostic tests, treatment and palliative measures ${ }^{(4)}$.

The role of the nurse as the professional responsible for the medication administration process is recognized as being the leader of the nursing team ${ }^{(5)}$ and as the last barrier in the medication system to identify and intercept the errors ${ }^{(6)}$.

Therefore, it is necessary to incorporate a tool that can identify the risk-generating conditions for the occurrence of Adverse Drug Events in nursing care practice.

\section{OBJECTIVE}

This study aims to build and validate the Patient Safety Assessment in Medication Administration (ASPAM) tool.

\section{METHOD}

\section{Ethical aspects}

In compliance with the recommendations of Resolution $466 / 2012$ of the National Health Council (Conselho Nacional de Saúde), which governs the research process with human beings, the study was submitted, evaluated and approved by the Ethics and Research Committee of the Universidade Federal do Ceará. The collection of data began with the signing of a Free and Informed Consent Term by the nursing professionals, leaving a copy with them.

\section{Design, place of study and period}

Methodological study of the construction and validation of the Patient Safety Assessment in Medication Administration (ASPAM) tool, performed with nursing professionals working in hospitalization units of two pediatric hospitals in Fortaleza, Ceará, Brazil, from January to March, 2016.

\section{Population or sample: Inclusion and exclusion criteria}

The content validation sample was composed of seven judges, who were selected through intentional sampling, having a Doctorate Degree and attending the minimum score of five points, according to criteria adapted for selection of judges, namely: Possess dissertation/thesis (2 points/work); have authorship in at least one paper published in a journal (1 point/work); participate in research groups/ projects (1 point); have teaching experience (1 point/year); to have a practical performance in the hospitalization unit ( 0.5 point/year); and to have oriented thesis, dissertation or monograph ( 0.5 point/ work), all related to the themes of the area of interest (Construction and validation of tools in the area of Nursing, Child care in hospitalization units, Child Health and Safety of the patient) ${ }^{(7)}$.

For the analysis of construct validity and reliability, a sample of 184 nursing professionals (Nurses, Technicians and Nursing Assistants), who met the inclusion criteria: Acting in the process of medication administration to the children hospitalized in the units study for at least six months. Professionals who were on vacation, on leave or away from activities during the period of data collection were excluded.

\section{Study protocol}

Data collection was performed in two stages: Construction; and analysis of validity (content and construct) and reliability ${ }^{(8)}$.

The construction of the evaluation tool was developed in light of the Safety, Prescription, Use and Administration of Medication Protocol ${ }^{(4)}$, which is divided into three sections, including safe practices for prescription, distribution of medications and administration of medications, in which there are proposals for interventions (verification items), a standard operating procedure and monitoring indicators.

The tool construction step was performed by analyzing the verification items of the Safety, Prescription, Use and Administration of Medication Protocol, for the identification of interventions related to the construct safety in medication administration.

In order to analyze the validity of content, each item of the first version of the tool was evaluated by the judges' committee regarding the criteria of simplicity, clarity and relevance ${ }^{(9)}$, based on a Likert Scale with the following indicators: 1 - very bad, 2 - bad, 3 - regular, 4 - good and 5 -excellent. In addition, this tool included a place for suggestions. The judges had a period of 15 days to finish such an analysis.

For the analysis of construct validity and reliability, the second version of the tool was delivered to 184 nursing professionals, in their respective working environments, at the time when they were willing to participate in the study. The professionals returned the tools answered at the end of each shift or at the subsequent shift.

The construct analysis was performed by exploratory factorial analysis and the reliability was evaluated in terms of homogeneity, from Cronbach's Alpha.

\section{Analysis of results and statistics}

The Content Validity Index (CVI) was calculated from the average number of responses " 4 " and " 5 " selected by the judges ${ }^{(10)}$. In order to verify the validity of the tool regarding the content, the value of concordance $>0.8$ was chosen between the judges ${ }^{(9)}$. 
The factorial analysis was obtained through the correlation matrix, Kaiser-Meyer-Olkim criterion, Bartlett's Sphericity Test and the slope diagram (scree plot rule). In the correlation matrix, it is recommended that only items with coefficients $>0.3^{(11)}$.

Reliability was verified by internal consistency as measured by Cronbach's Alpha. This coefficient ranges from 0 to 1, with zero indicating the total absence of internal consistency of the items, and 1 consistency of $100 \%$. Acceptable alpha values are between 0.70 and $0.90^{(9)}$.

\section{RESULTS}

In the construction phase of the ASPAM, by means of analysis of the verification items for the administration of medications proposed by the Safety, Prescription, Use and Administration of Medication Protocol(4), 28 actions were selected, which were transformed into precursor items of ASPAM (Chart1). According to the national recommendation ${ }^{(4)}$, the items were stratified into nine domains, established on the basis of the nine principles of medication administration, namely: Right patient, right medication, right route, right time, right dose, right guidance, right way, and right answer (Chart 2).

The selected items were grouped in a measurement tool with fixed response format, Likert scale (1 - never, 2 - almost never, 3 - sometimes, 4 - almost always and 5 - always), in which the professional should respond by selecting only one option, so that only the response is always considered an adequate frequency for the safe performance of the medication administration actions performed by the nursing team in their care routine.
The content validity stage was carried out by a committee composed of seven judges, all female nurses, aged between 34 and 46 years and with training time ranging from 9 to 22 years. All of them had a minimum Doctor Degree, of which four (57.1\%) had a thesis in the Pediatrics and/or Patient Safety, and one of them had a PhD in Nursing. All referred experience in areas of interest from 2 to 17 years. It should be noted that the seven judges met beyond the minimum number of points required, averaging 15.2 points. Chart 1 presents the $\mathrm{CVI}$ for each item of the tool, the total CVI according to the criteria evaluated (simplicity, clarity and relevance), as well as the correlation between the first and second version of the tool.

The criteria of simplicity and clarity had fifteen items with CVI below 0.80 (cutoff point) and resulted in a total CVI of 0.77 and 0.76 , respectively. For the criterion of relevance, only three items presented $\mathrm{CVI}<0.80$, reaching a total $\mathrm{CVI}$ of 0.94 .

It is worth noting that in spite of the recommendation that only items with a $\mathrm{CVI}>0.8$ be considered acceptable, it was decided not to remove the items from the scale so that the construct validity and reliability could be analyzed later, nine items were maintained, eleven had their content modified, four were divided and four were excluded, obtaining the second version of the ASPAM tool with 28 items (Chart 1).

For the validation of construct and reliability, the second version of ASPAM was applied to 184 nursing professionals, of which 52 (28.2\%) were nurses, 103 (56\%) nursing technicians and $29(15.8 \%)$ nursing assistants, with a mean age of $38.9+9.7$ and training time $(81.3 \%)$ and professional experience $(79.8 \%)$ over five years.

Chart 1 - Items-criteria correlation for evaluation of the validation of content of the Patient Safety Assessment in Medication Administration (ASPAM) tool, Fortaleza, Brazil, 2016

\begin{tabular}{|c|c|c|c|c|}
\hline \multirow{2}{*}{ Items of the $1^{\text {st }}$ version of the tool } & \multicolumn{3}{|c|}{$\begin{array}{l}\text { Content Validity } \\
\text { Coefficient }\end{array}$} & \multirow{2}{*}{ Items of the $2^{\text {nd }}$ version of the tool } \\
\hline & $\mathbf{S}^{*}$ & $\mathbf{C}^{\S}$ & $\mathbf{R}^{ \pm}$ & \\
\hline $\begin{array}{l}\text { 1. Uses at least two identifiers to confirm the right patient } \\
\text { before administering medications. }\end{array}$ & 0.85 & 0.57 & 1 & $\begin{array}{l}\text { 1. Uses at least two identifiers (full name and medical } \\
\text { record number) to confirm the patient before administering } \\
\text { the medication. }\end{array}$ \\
\hline $\begin{array}{l}\text { 2. Verifies the name of the prescription medication before } \\
\text { administering it. }\end{array}$ & 1 & 0.85 & 1 & $\begin{array}{l}\text { 2. Verifies the name of the prescription medication before } \\
\text { administering it. }\end{array}$ \\
\hline $\begin{array}{l}\text { 3. Brings to the bed only what is prescribed to a single } \\
\text { patient, not using a tray containing several medications for } \\
\text { different patients. }\end{array}$ & 0.71 & 0.71 & 1 & $\begin{array}{l}\text { 3. Brings to the bed only the medications prescribed to a } \\
\text { single patient. }\end{array}$ \\
\hline $\begin{array}{l}\text { 4. Administers medication by verbal order only in case of } \\
\text { emergency, with written record of the verbal order. }\end{array}$ & 0.57 & 0.57 & 0.85 & $\begin{array}{l}\text { 4. Administers medication by verbal order only in case of } \\
\text { emergency. }\end{array}$ \\
\hline \multirow{2}{*}{$\begin{array}{l}\text { 5. Checks if patient is allergic to the prescribed medication, } \\
\text { identifying the allergic patient in a differentiated way, with a } \\
\text { bracelet and a warning on the chart, alerting the whole team. }\end{array}$} & \multirow[b]{2}{*}{0.57} & \multirow[b]{2}{*}{0.71} & \multirow[b]{2}{*}{1} & 5. Checks if patient is allergic to the prescribed medication. \\
\hline & & & & $\begin{array}{l}\text { 6. Identifies the allergic patient in a differentiated way with } \\
\text { a bracelet and a medical record, alerting the whole team. }\end{array}$ \\
\hline \multirow{2}{*}{$\begin{array}{l}\text { 6. Identifies the prescribed route of administration, verifying } \\
\text { if it is the technically recommended route of administration } \\
\text { for a given medication. }\end{array}$} & \multirow{2}{*}{0.71} & \multirow{2}{*}{0.71} & \multirow{2}{*}{1} & $\begin{array}{l}\text { 7. Identifies the route of administration prescribed for the } \\
\text { medication. }\end{array}$ \\
\hline & & & & $\begin{array}{l}\text { 8. Checks if the prescribed route is technically } \\
\text { recommended for administering the medication. }\end{array}$ \\
\hline $\begin{array}{l}\text { 7. Washes hands before preparation and administration of } \\
\text { medications. }\end{array}$ & 1 & 1 & 1 & $\begin{array}{l}\text { 9. Washes hands before preparation and administration of } \\
\text { medications. }\end{array}$ \\
\hline $\begin{array}{l}\text { 8. Uses aseptic materials and techniques to administer } \\
\text { medications intravenously and to other routes requiring this } \\
\text { type of technique. }\end{array}$ & 0.71 & 0.71 & 0.85 & $\begin{array}{l}\text { 10. Uses aseptic materials and techniques to administer } \\
\text { medications. }\end{array}$ \\
\hline
\end{tabular}




\begin{tabular}{|c|c|c|c|c|}
\hline \multirow{2}{*}{ Items of the $1^{\text {st }}$ version of the tool } & \multicolumn{3}{|c|}{$\begin{array}{l}\text { Content Validity } \\
\text { Coefficient }\end{array}$} & \multirow{2}{*}{ Items of the $2^{\text {nd }}$ version of the tool } \\
\hline & $\mathbf{S}^{*}$ & $\mathbf{C}^{\S}$ & $\mathbf{R}^{£}$ & \\
\hline $\begin{array}{l}\text { 9. Prepares the medication immediately prior to its } \\
\text { administration, obeying the schedule of the prescription. }\end{array}$ & 0.71 & 0.71 & 1 & $\begin{array}{l}\text { 11. Prepares the medication immediately prior to its } \\
\text { administration. }\end{array}$ \\
\hline 10. Administers the medication at the right time. & 0.71 & 0.85 & 1 & 12. Administers the medication at the right time. \\
\hline $\begin{array}{l}\text { 11. In cases of patient preparation for exams or fasting, do not } \\
\text { administer or postpone the administration of doses without } \\
\text { discussing conduct with the prescriber. }\end{array}$ & 0.71 & 0.57 & 0.85 & Excluded \\
\hline $\begin{array}{l}\text { 12. Adjusts the administration times of the medications to the } \\
\text { routine of use already established before the hospitalization. }\end{array}$ & 1 & 1 & 1 & $\begin{array}{l}\text { 13. Adjusts the administration times of the medications } \\
\text { to the routine of use already established before the } \\
\text { hospitalization. }\end{array}$ \\
\hline $\begin{array}{l}\text { 13. Discusses the prevention of medication-medication and } \\
\text { medication-food interactions with the multiprofessional team. }\end{array}$ & 0.71 & 0.71 & 1 & Excluded \\
\hline 14. Carefully checks the dose prescribed for the medication. & 1 & 1 & 1 & 14. Carefully checks the dose prescribed for the medication. \\
\hline $\begin{array}{l}\text { 15. Makes sure that the scheduled infusion is the one } \\
\text { prescribed for that patient. }\end{array}$ & 0.85 & 0.71 & 0.71 & Excluded \\
\hline $\begin{array}{l}\text { 16. Confers the drip speed, programming and operation of } \\
\text { continuous infusion pumps with the prescription. }\end{array}$ & 0.85 & 1 & 1 & $\begin{array}{l}\text { 15. Checks the drip speed, programming and operation of } \\
\text { continuous infusion pumps with the prescription. }\end{array}$ \\
\hline $\begin{array}{l}\text { 17. Performs double check of calculations for preparation and } \\
\text { for administration of potentially dangerous or high vigilance } \\
\text { medications. }\end{array}$ & 1 & 1 & 1 & $\begin{array}{l}\text { 16. Performs double check of calculations for preparation } \\
\text { and for administration of potentially dangerous or high } \\
\text { vigilance medications. }\end{array}$ \\
\hline $\begin{array}{l}\text { 18. Uses standard measuring tools to prepare medications to } \\
\text { measure doses accurately (e.g., millimeter syringes). }\end{array}$ & 1 & 1 & 1 & $\begin{array}{l}\text { 17. Uses standard measuring tools to prepare medications to } \\
\text { measure doses accurately (e.g., millimeter syringes). }\end{array}$ \\
\hline $\begin{array}{l}\text { 19. Returns leftover unadministered medications to the } \\
\text { pharmacy. }\end{array}$ & 0.85 & 0.85 & 1 & $\begin{array}{l}\text { 18. Returns leftover unadministered medications to the } \\
\text { pharmacy. }\end{array}$ \\
\hline $\begin{array}{l}\text { 20. Checks the timing of administration of the medication } \\
\text { immediately after each dose. }\end{array}$ & 0.57 & 0.57 & 1 & $\begin{array}{l}\text { 19. Records the time of administration of the medication } \\
\text { immediately after each dose. }\end{array}$ \\
\hline \multirow{2}{*}{$\begin{array}{l}\text { 21. Records all medication-related occurrences (delays, } \\
\text { cancellations, discontinuation, patient refusal and adverse } \\
\text { events) and the different effects (in intensity and form) } \\
\text { expected from the medication described by the patient/ } \\
\text { companion or observed for the team. }\end{array}$} & \multirow[t]{2}{*}{0.57} & \multirow[t]{2}{*}{0.57} & \multirow[t]{2}{*}{1} & $\begin{array}{l}\text { 20. Records all medication-related events (e.g., } \\
\text { postponements, cancellations, shortages, patient refusals, } \\
\text { side effects, and adverse events). }\end{array}$ \\
\hline & & & & $\begin{array}{l}\text { 28. Informs the prescriber of all effects other than expected } \\
\text { (in intensity and shape) for the medication. }\end{array}$ \\
\hline \multirow{2}{*}{$\begin{array}{l}\text { 22. Guides the patient and the caregiver about the medication } \\
\text { administered (name), aspect (color and shape), justification of } \\
\text { the indication, frequency with which it will be administered, } \\
\text { expected effects, possible incidents related to the medication } \\
\text { therapy, registering them in medical records and notifying } \\
\text { them to the Risk Management and/or the Patient Safety Center. }\end{array}$} & \multirow[b]{2}{*}{0.57} & \multirow[b]{2}{*}{0.57} & \multirow[b]{2}{*}{0.71} & $\begin{array}{l}\text { 21. Notifies the Risk Management and/or Patient Safety } \\
\text { Center of any incidents related to medication therapy. }\end{array}$ \\
\hline & & & & $\begin{array}{l}\text { 25. Guides the patient and the companion about the name } \\
\text { of the medication administered, aspect (color and shape), } \\
\text { justification of the indication, frequency with which it will be } \\
\text { administered and expected effects. }\end{array}$ \\
\hline $\begin{array}{l}\text { 23. Checks whether the medication to be administered } \\
\text { has the pharmaceutical form and route of administration } \\
\text { prescribed. }\end{array}$ & 0.42 & 0.42 & 0.71 & $\begin{array}{l}\text { 26. Checks if the medication to be administered is in a } \\
\text { pharmaceutical form (e.g., Ampoule, vial, tablet) compatible } \\
\text { with the prescribed route of administration. }\end{array}$ \\
\hline $\begin{array}{l}\text { 24. Observes the patient to identify, if possible, whether the } \\
\text { medication had the desired effect. }\end{array}$ & 0.71 & 0.85 & 1 & $\begin{array}{l}\text { 27. Evaluates the patient to identify, if possible, whether the } \\
\text { medication has the desired effect. }\end{array}$ \\
\hline $\begin{array}{l}\text { 25. Clarifies doubts about the readability of the prescription, the } \\
\text { indication of the medication, its dosage, vacuous prescription } \\
\text { ("do if necessary","'at medical discretion"), unit of measures used, } \\
\text { pharmaceutical form, route of administration and dose directly } \\
\text { with the prescriber. }\end{array}$ & 0.85 & 0.85 & 0.85 & $\begin{array}{l}\text { 24. Clarifies doubts about prescribing before the prescriber } \\
\text { before administering the medication (e.g., Ineligibility } \\
\text { of prescription, indication of the medication, dosage, "if } \\
\text { necessary","at medical discretion", unit of measures used, } \\
\text { pharmaceutical form, route of administration and dose). }\end{array}$ \\
\hline 26. Only administers the medication if the doubts are cleared. & 0.71 & 0.71 & 1 & Excluded \\
\hline $\begin{array}{l}\text { 27. Keeps standardization regarding adequate storage and } \\
\text { complete and clear identification (with date and time of the } \\
\text { manipulation, concentration of the medication, name of the } \\
\text { person responsible for the preparation and validity) of all } \\
\text { medications that are under the care of the nursing team. }\end{array}$ & 0.85 & 0.85 & 0.85 & $\begin{array}{l}\text { 22. Keeps adequate records of prepared medications to be } \\
\text { stored (date and time of the manipulation, concentration } \\
\text { of the medication, name of the person responsible for the } \\
\text { preparation and validity). }\end{array}$ \\
\hline $\begin{array}{l}\text { 28. Monitors the temperature of the medication packaging } \\
\text { refrigerator, recording the maximum and minimum values } \\
\text { daily. }\end{array}$ & 1 & 1 & 1 & $\begin{array}{l}\text { 23. Monitors the temperature of the medication packaging } \\
\text { refrigerator, recording the maximum and minimum values } \\
\text { daily. }\end{array}$ \\
\hline Total Criterion Content Validity Coefficient & 0.77 & 0.76 & 0.94 & \\
\hline
\end{tabular}


For the factor analysis, five cases were considered for each item of the tool, which resulted in a ratio of 6.57, considered adequate according to the literature ${ }^{(11)}$. The Kaiser-Meyer-Olkin (KMO) measurement reached a coefficient of 0.66 , exceeding the recommended minimum value of $0.6^{(12)}$, and Bartlett's sphericity test ${ }^{(13)}$ reached statistical significance $(p<0.001)$, confirming the adequacy of the factorial analysis for the present study.

The analysis of the main components revealed eight components with eigenvalues $>1$, in this case eight domains, which would explain $68.7 \%$ of the total variance of the data (Table $1)$, which was confirmed by the analysis of the slope diagram scree plot) (Figure 1).

It should be pointed out that, although the analysis of the main components and the slope diagram reveals that only eight components could be extracted, nine factors (domains) were prefixed, since they represent the nine administration of national ${ }^{(4)}$ and internationally standardized medications ${ }^{(14)}$.

Cronbach's Alpha of ASPAM with its 28 items was 0.85 , indicating high internal consistency of the tool. Considering the removal of items 23 and 28, which most contribute to the increase and reduction of tool reliability, the Cronbach's Alpha, respectively, ranged from 0.841 to 0.855 , characterizing the tool as reliable in its final version (Table 2). Thus, Cronbach's Alpha indicated a high internal consistency of the tool, ratifying the maintenance of the 28 items, even of those who had $\mathrm{CVI}<0.8$.

Table 1 - Explained variance (eigenvalues) and percentages of variation of each item of the tool, Fortaleza, Brazil, 2016

\begin{tabular}{cccc}
\hline Component & Total Variance & \% of variance & \% cumulative \\
\hline 1 & 6.897 & 24.633 & 24.633 \\
2 & 2.676 & 9.557 & 34.190 \\
3 & 2.492 & 8.900 & 43.090 \\
4 & 1.985 & 7.090 & 50.179 \\
5 & 1.568 & 5.601 & 55.780 \\
6 & 1.327 & 4.738 & 60.519 \\
7 & 1.143 & 4.082 & 64.600 \\
8 & 1.138 & 4.063 & 68.663 \\
9 & 0.956 & 3.413 & 72.076 \\
\hline
\end{tabular}

Note - Extraction method: Analysis of the main components.

Therefore, the tool Patient Safety Assessment in Medication Administration was constituted by nine domains, these being: Right patient (item 1), right medication (items 2 to 6), right way (items 7 to 10), right time (items 11 (items 14 to 18), right register (items 19 to 23), right guidance (items 24 and 25), right form (item 26) and right answer (items 27 and 28), making a total of 28 items (Chart 2)

For the evaluation of the performance of each action, the performance was adopted as satisfactory; whose cut-off point was equal to or greater than $70 \%{ }^{(15-16)}$. For the evaluation of the performance of professionals in each action of the administration
Scree plot

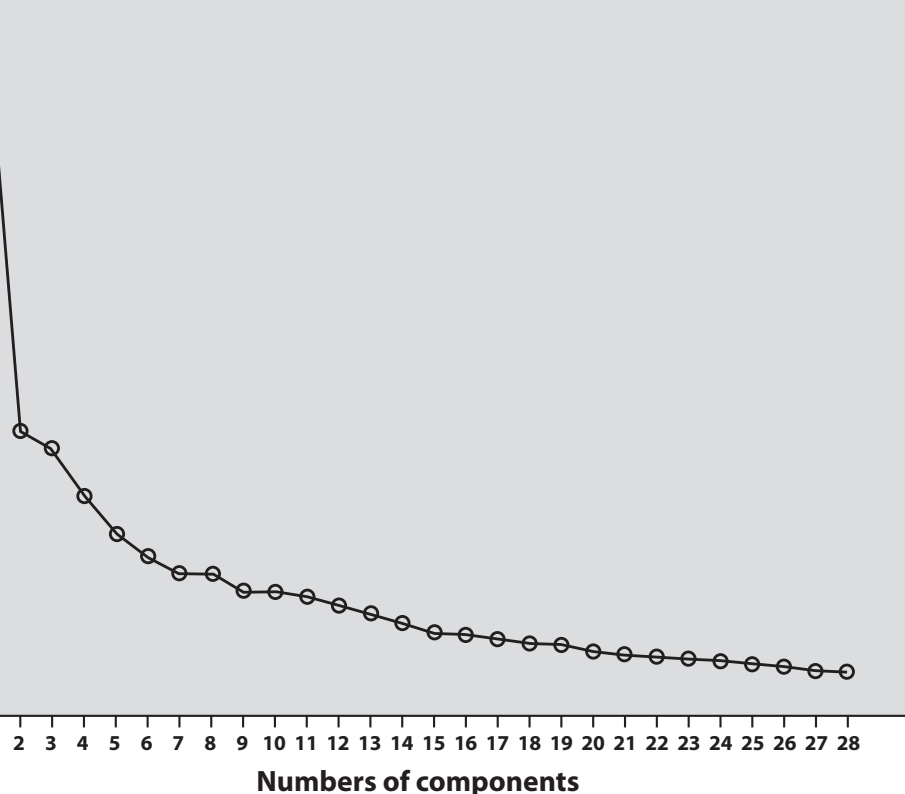

Numbers of components

Figure 1 - Scree plot, considering the eigenvalues and number of components (domains) of the tool, Fortaleza, Brazil, 2016

of medications, the Positivity Index (PI) for Quality of Care was defined as desirable $(\mathrm{PI}=100 \%)$, adequate $(90 \%<\mathrm{PI}<99 \%)$, insurance $(80 \%<\mathrm{PI}<89 \%)$, safe $(71 \%<\mathrm{PI}<79 \%)$ and low $(\mathrm{PI}<70 \%)^{(17)}$.

Table 2 - Cronbach's Alpha values in the absence of any of the tool's items, Fortaleza, Ceará, Brazil, 2016

\begin{tabular}{|c|c|}
\hline Item & Cronbach's Alpha if the item is excluded \\
\hline 1 & 0.843 \\
\hline 2 & 0.850 \\
\hline 3 & 0.848 \\
\hline 4 & 0.849 \\
\hline 5 & 0.846 \\
\hline 6 & 0.853 \\
\hline 7 & 0.847 \\
\hline 8 & 0.844 \\
\hline 9 & 0.850 \\
\hline 10 & 0.845 \\
\hline 11 & 0.845 \\
\hline 12 & 0.846 \\
\hline 13 & 0.843 \\
\hline 14 & 0.849 \\
\hline 15 & 0.851 \\
\hline 16 & 0.844 \\
\hline 17 & 0.842 \\
\hline 18 & 0.844 \\
\hline 19 & 0.848 \\
\hline 20 & 0.842 \\
\hline 21 & 0.836 \\
\hline 22 & 0.846 \\
\hline 23 & 0.855 \\
\hline 24 & 0.845 \\
\hline 25 & 0.842 \\
\hline 26 & 0.848 \\
\hline 27 & 0.842 \\
\hline 28 & 0.841 \\
\hline
\end{tabular}


Chart 2 - Final version of the Patient Safety Assessment in Medication Administration (ASPAM) tool, Fortaleza, Brazil, 2016

\begin{tabular}{|c|c|c|c|c|c|c|}
\hline \multirow{3}{*}{ 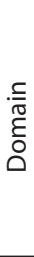 } & \multirow{3}{*}{$\begin{array}{l}\text { Patient Safety Assessment in } \\
\text { Medication Administration }\end{array}$} & \multicolumn{5}{|c|}{ Frequency } \\
\hline & & 㐫 & 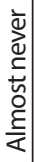 & & 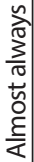 & $\sum_{\substack{0 \\
\frac{\pi}{4}}}^{n}$ \\
\hline & & 1 & 2 & 3 & 4 & 5 \\
\hline 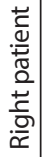 & $\begin{array}{l}\text { 1. Uses at least two identifiers (full name and medi- } \\
\text { cal record number) to confirm the patient before } \\
\text { administering the medication. }\end{array}$ & & & & & \\
\hline \multirow{5}{*}{ 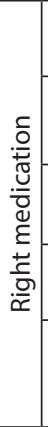 } & $\begin{array}{l}\text { 2. Verifies the name of the prescription medication } \\
\text { before administering it. }\end{array}$ & & & & & \\
\hline & $\begin{array}{l}\text { 3. Brings to the bed only the medications prescribed } \\
\text { to a single patient. }\end{array}$ & & & & & \\
\hline & $\begin{array}{l}\text { 4. Administers medication by verbal order only in } \\
\text { case of emergency. }\end{array}$ & & & & & \\
\hline & $\begin{array}{l}\text { 5. Checks if patient is allergic to the prescribed medi- } \\
\text { cation. }\end{array}$ & & & & & \\
\hline & $\begin{array}{l}\text { 6. Identifies the allergic patient in a differentiated } \\
\text { way with a bracelet and a medical record, alerting } \\
\text { the whole team. }\end{array}$ & & & & & \\
\hline \multirow{4}{*}{ 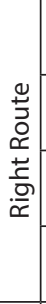 } & $\begin{array}{l}\text { 7. Identifies the route of administration prescribed } \\
\text { for the medication. }\end{array}$ & & & & & \\
\hline & $\begin{array}{l}\text { 8. Checks if the prescribed route is technically rec- } \\
\text { ommended for administering the medication. }\end{array}$ & & & & & \\
\hline & $\begin{array}{l}\text { 9. Washes hands before preparation and adminis- } \\
\text { tration of medications. }\end{array}$ & & & & & \\
\hline & $\begin{array}{l}\text { 10. Uses aseptic materials and techniques to admin- } \\
\text { ister medications. }\end{array}$ & & & & & \\
\hline \multirow{3}{*}{ 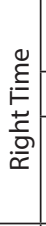 } & $\begin{array}{l}\text { 11. Prepares the medication immediately prior to its } \\
\text { administration. }\end{array}$ & & & & & \\
\hline & 12. Administers the medication at the right time. & & & & & \\
\hline & $\begin{array}{l}\text { 13. Adjusts the administration times of the medica- } \\
\text { tions to the routine of use already established } \\
\text { before the hospitalization. }\end{array}$ & & & & & \\
\hline \multirow{5}{*}{ 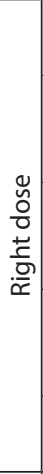 } & $\begin{array}{l}\text { 14. Carefully checks the dose prescribed for the medi- } \\
\text { cation. }\end{array}$ & & & & & \\
\hline & $\begin{array}{l}\text { 15. Checks the drip speed, programming and opera- } \\
\text { tion of continuous infusion pumps with the pre- } \\
\text { scription. }\end{array}$ & & & & & \\
\hline & $\begin{array}{l}\text { 16. Performs double check of calculations for prepa- } \\
\text { ration and for administration of potentially dan- } \\
\text { gerous or high vigilance medications. }\end{array}$ & & & & & \\
\hline & $\begin{array}{l}\text { 17. Uses standard measuring tools to prepare medi- } \\
\text { cations to measure doses accurately (e.g., mil- } \\
\text { limeter syringes). }\end{array}$ & & & & & \\
\hline & $\begin{array}{l}\text { 18. Returns leftover unadministered medications to } \\
\text { the pharmacy. }\end{array}$ & & & & & \\
\hline \multirow{3}{*}{ 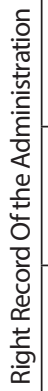 } & $\begin{array}{l}\text { 19. Records the time of administration of the medi- } \\
\text { cation immediately after each dose. }\end{array}$ & & & & & \\
\hline & $\begin{array}{l}\text { 20. Records all medication-related events (e.g., post- } \\
\text { ponements, cancellations, shortages, patient re- } \\
\text { fusals, side effects, and adverse events). }\end{array}$ & & & & & \\
\hline & $\begin{array}{l}\text { 21. Notifies the Risk Management and/or Patient } \\
\text { Safety Center of any incidents related to medica- } \\
\text { tion therapy. }\end{array}$ & & & & & \\
\hline
\end{tabular}

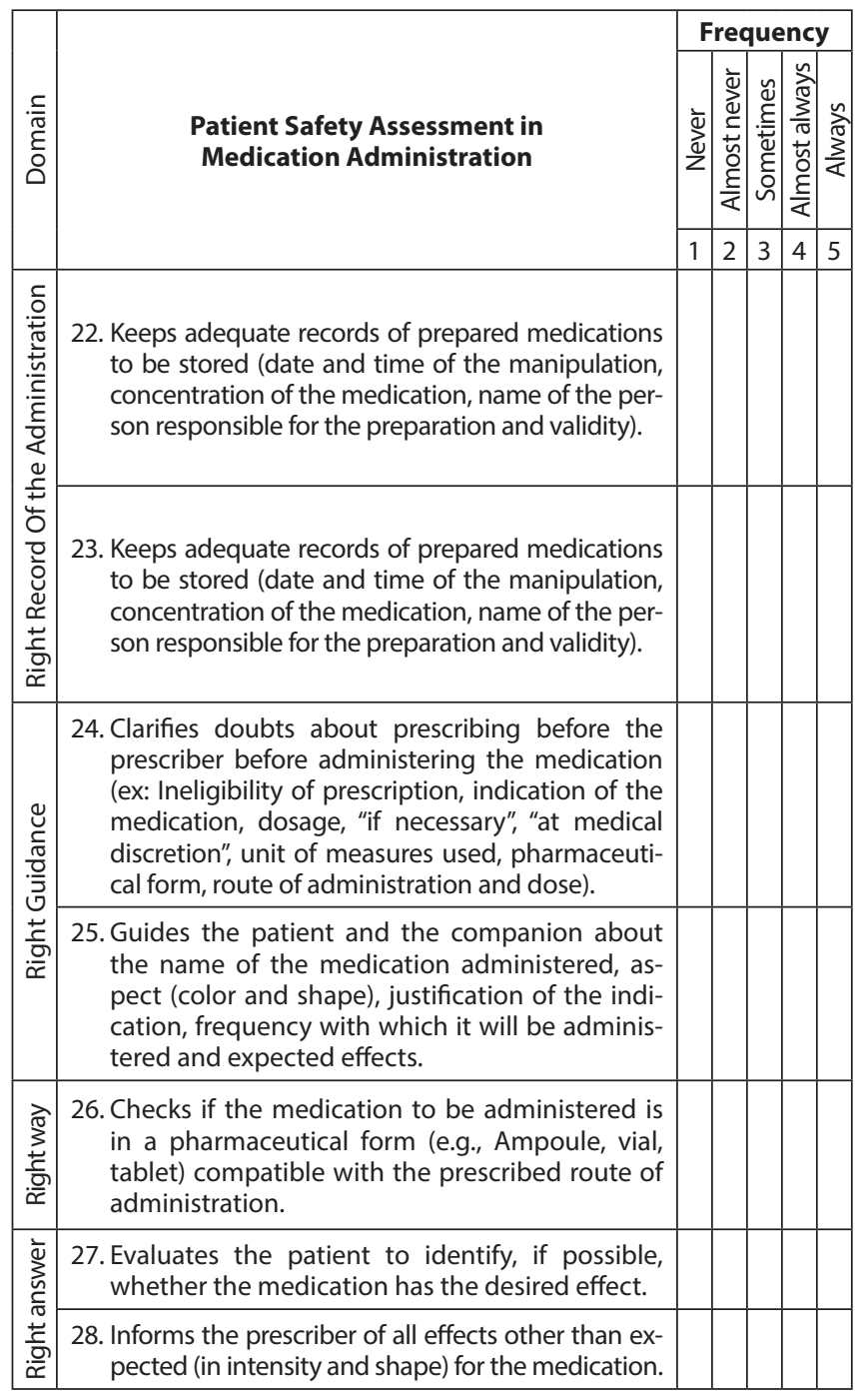

\section{DISCUSSION}

The results of the analysis of the items by the judges' committee indicate that the tool is representative of the relevance of the content; however, it needed reformulation as to the simplicity and clarity of the items that compose it. Therefore, in order to make the items considered unclear and of little simple language adequate, a good part of the judges' suggestions were accepted, including some items that had reached adequate levels of agreement were restructured, seeking a better understanding of the same, as already observed in the literature ${ }^{(7,18)}$.

In response to the request of the judges, examples of identifiers were added in the description of item 1 because they believed that the term "identifiers" might not be clear to all professionals.

Patient identifiers aim to standardize the identification approaches among the different units and institutions within a health system ${ }^{(1)}$. The most well-known indicators among health professionals are"full name of the patient" and "record number"(medical record) (19), which were added as examples to item 1. For similar reasons, examples were also added of forms presentation to item 22.

It was also agreed to subtract from paragraph 3 the sentence "not using a tray containing several medications for different 
patients", considering that the errors involving the administration of the medication are associated with the nonconference of the medication and agglomeration of several types in single tray, which contributes to the exchange of the same at the time of application $^{(20)}$, a practice still evidenced among nursing professionals ${ }^{(21-22)}$.

The extraction of the sentence "with written record of the verbal order" in item 4 was also attended, since it is up to the prescriber, not the nursing professional, to validate in the prescription medications administered during an emergency situation ${ }^{(4)}$.

Although items 22 and 23 obtained CVI for relevance $<0.80$, the researchers chose to keep them in the questionnaire because they believe that both represent outstanding actions in the evaluation of the domains in the right way and the right answer. The items, however, were reformulated according to the judges' considerations.

Thus, ASPAM has proved to be a valid tool for the identification of risk-generating conditions for safety in medication administration, which demonstrates that it is suitable for the intended purpose and with a high degree of reliability because it obtained a value of 0.85 for Cronbach's Alpha, which demonstrates that the items of the tool are correlated ${ }^{(23)}$.

It should be noted that, in the context of the present study, it was unnecessary to analyze the magnitude of the correlations and the conceptual adequacy of each item within each factor (domain) since the tool was constructed in the light of the verification items proposed for the implementation of the nine pillars of medication administration per protocol in Brazil(4).

\section{Study limitations}

Some limitations need to be considered for the extrapolation of the results found in this study, such as: the difficulty of adhering to the nurses in valuing and adhering to the research, demonstrated by the number of tools that were not returned during the data collection $(n=32)$ and the conditioning of the collection of data with the professionals to the routine and the unpredictability of the demand of each sector. Despite these limitations, it is important to note that a suitable sample size was used for the necessary statistical analysis, as recommended in the relevant literature.

\section{Contributions for the sectors of Nursing, Health or Public Policy}

The study brings advances to Nursing as it makes available the Patient Safety Assessment in Medication Administration as a valid and reliable technological resource in the identification of risk generating conditions; and offers subsidies that contribute to study the relationship between errors and habits of the work organization of the nursing team, aiming to improve the quality of care provided and thus promote the safety of hospitalized patients.

\section{CONCLUSION}

The study reached the proposed goal regarding the construction and validation of the Patient Safety Assessment in Medication Administration, demonstrating that it is a validated and reliable tool for the identification of risk-generating conditions related to the medication practice by the nursing team.

It is suggested, however, that new studies should be carried out, aiming to verify the reliability of the tool based on an observational methodology, due to the need to confront the results obtained from the self-report of professionals.

\section{REFERENCES}

1. World Health Organization-WHO. World Alliance for Patient Safety. Taxonomy. The Conceptual Framework for the International Classification for Patient Safety: final technical report. Geneva (Switzerland):World Health Organization; 2009.

2. Sanches LS, Giordani F, Teleken JL, Leivas AFG, Schmidt RC, Balbinot JC, Garbuio APM, Pianna SC. Uso de rastreadores para detecção de eventos adversos aos medicamentos em hospital universitário. Ciênc Saúde [Internet]. 2016[cited 2018 Jan 20];9(3):190-96. Available from: http://revistaseletronicas.pucrs.br/ojs/index.php/faenfi/article/view/24345/15034

3. Vilela RPB, Jericó MC. Medication errors: management of the medication error indicator toward a more safety nursing practice. Rev Enferm UFPE[Internet]. 2015[cited 2018 Jan 20];10(1):119-27. Available from: https://periodicos.ufpe.br/revistas/revistaenfermagem/article/ view/10929

4. Ministério da Saúde (BR). Anexo 3: Protocolo de Segurança na prescrição, uso e administração de medicamentos. Brasília (DF): ANVISA, FIOCRUZ e FHEMIG, 2013. 46 p.

5. Presidência da República (BR), Casa Civil, Subchefia para Assuntos Jurídicos. Lei n. 7.498, de 25 de junho de 1986. Dispõe sobre a regulamentação do exercício da enfermagem e dá outras providências [Internet]. Diário Oficial da União: República Federativa do Brasil; 1986 [cited 2019 Mar 12]. Jun 25. Seção 1: [about 5 screens]. Available from: http://www.planalto.gov.br/CCivil_03/LEIS/L7498.htm

6. Ofosu R, Jarrett P. Reducing nurse medicine administration errors. Nurs Times. 2015; 111 (20):12-14.

7. Joventino ES, Oriá MOB, Sawada NO, Ximenes LB. Validação aparente e de conteúdo da escala de autoeficácia materna para prevenção da diarreia infantil. Rev Latino-Am Enfermagem[Internet]. 2013[cited 2018 Jan 20];21(1):[09 telas]. Available from: http://www.redalyc.org/ $\mathrm{html} / 2814 / 281425765012 /$

8. Lobiondo-Wood G, Haber J. Pesquisa em Enfermagem: métodos, avaliação crítica e utilização. $4^{a}$ ed. Rio de Janeiro: Guanabara-Koogan. 2001.

9. Pasquali L. Instrumentação psicológica: fundamentos e práticas. Porto Alegre (RS): Artmed; 2010. 
10. Lopes CMM, Haas VJ, Dantas RAS, Oliveira CG, Galvão CM. Escala de avaliação de risco para lesões decorrentes do posicionamento cirúrgico. Rev Latino-Am Enfermagem[Internet]. 2016[cited 2018 Jan 20];24:e2704. Available from: http://www.redalyc.org/pdf/2814/281449727012.pdf.

11. Tabachnick BG, Fidell LS. Using multivariate statistics. New York: Harper Collins, 2001.

12. Kaiser H. An index of factorial simplicity. Psychomethika. 1974; 39(41):31-36.

13. Bartlett MS. A note on multiplying factors for various chi-squared approximations. J Royal Statistical Soc, Series B. 1954; 16: $296-298$.

14. Elliott M, Liu Y. The nine rights of medication administration: an overview. British J Nurs. 2010; 19(5):300-305.

15. Mota RO, Eva Brito AWS, Souza TLV, Farias LMVC, Matias EO, Lima FET. Preparo de medicamentos administrados via intramuscular na pediatria: atuação da equipe de enfermagem. Cogitare Enferm[Internet]. 2016[cited 2018 Jan 20];21(Esp):01-09. Available from: https:// revistas.ufpr.br/cogitare/article/view/45619

16. Torres MM, Andrade D, Santos CB. Punção venosa periférica: avaliação de desempenho dos profissionais de enfermagem. Rev Latino-Am Enfermagem[Internet]. 2005[cited 2018 Jan 20];13(3):299-304. Available from: http://www.revistas.usp.br/rlae/article/view/2085/2170

17. Murassaki ACY, Versa GLGS, Bellucci Jr JA, Meireles VC. Avaliação de cuidados na terapia intravenosa: desafio para a qualidade na enfermagem. Esc Anna Nery[Internet]. 2013[cited 2018 Jan 20];17(1):11-6. Available from: http://www.redalyc.org/pdf/1277/127728366002.pdf

18. Gomes ALA, Ximenes LB, Mendes ERR, Teixeira OCM, Joventino ES, Javorski M. Tradução e adaptação cultural da escala self-efficacy and their child's level of asthma control: versão brasileira. Texto Contexto Enferm[Internet]. 2016[cited 2018 Jan 20];25(3):e2950015. Available from: http://dx.doi.org/10.1590/0104-07072016002950015.

19. Hoffmeister LV, Moura GMSS. Uso de pulseiras de identificação em pacientes internados em um hospital universitário. Rev LatinoAm Enfermagem[Internet]. 2015[cited 2018 Jan 20];23(1):36-43. Available from: http://www.scielo.br/pdf/rlae/v23n1/pt_0104-1169rlae-23-01-00036.pdf.

20. Nguyen HT, Nguyen TD, van den Heuvel ER, Haaijer-Ruskamp FM, Taxis K. Medication errors in Vietnamese hospitals: prevalence, potential outcome and associated factors. PLoS ONE. 2015; 10(9):e0138284. doi: http://dx.doi.org/10.1371/journal.pone.0138284

21. Souza S, Rocha PK, Cabral PF, Kusahara DM. Utilização de estratégias de segurança na identificação da criança para administração de medicamentos. Acta Paul Enferm[Internet]. 2014[cited 2018 Jan 20];27(1):6-11. Available from: http://www2.unifesp.br/acta/pdf/v27/n1/ v27n1a6.pdf.

22. Galiza DDF, Moura OF, Barros VL, Luz GOA. Preparo e administração de medicamentos: erros cometidos pela equipe de enfermagem. Rev Bras Farm Hosp Serv Saúde[Internet]. 2014[cited 2018 Jan 20];5(2)45-50. Available from: http://www.sbrafh.org.br/rbfhss/public/ artigos/2014050205000528BR.pdf

23. Tavakol M, Dennick R. Making sense of Cronbach's alpha. Int J Med Educ [Internet]. 2011 [cited 2019 Mar 24];2:53-5. Available from: https:// doi.org/ 10.5116/ijme.4dfb.8dfd 